\title{
Dworkin on the Rule of Recognition
}

\author{
NANCY SNOW \\ University of Notre Dame
}

In the "Model of Rules I," Ronald Dworkin crit1cizes legal positivism, especially as articulated in the work of $H$. L. A. Hart, and suggests an alternative approach to legal theory that is neither a purely posttivist nor a purely natural law position.' In doing 80, he refects two fundamental tenets of positivism. The first is the idea that, In every developed legal gystem, there 18 a "master rule," or "rule of recognition," that 18, a social rule or complex set of rules that provides a test for identifying which rules are law and which are not. Th1s test has to do not with the content of rules, but with their pedigree, or the way in which they were adopted. The second tenet is the doctrine of judicial discretion. This is the thesis that, In deciding cases to which no law clearly applies, the fudge has no duty to find in favor of one litigant rather than another, but may use his or her discretion to generate new laws or modify old ones.

The rejection of both tenets seems paradoxical: if there is no commonly accepted test for law that would enable judges to recognize when they have a duty to declde a case in a particular way, and if they are not free to exerclise discretion, then how are legal cases to be decided? Some positivists have used the following argument to show that Dworkin is wrong in rejecting a social rule of recognition:

- . no rights or duties of any sort can exist except by virtue of a uniform social practice of recognizing these rights and duties. If that is go, and $1 f$ law is... a matter of rights and duties and not simply of the discretion of officials, then there must be a commoniy recognized test for law in the form of a uniform social practice...2

The argument rests on a particular theory of the origin of rights and duties in general, which Dworkin calls the "social rule theory." According to this theory, a social rule is described as "a rule constituted by the bulk of a population." "The theory. Dworkin contends, has two versions, atrong version and a weaker ver- 
sion. In rejecting the strong version's central claim that social rules constitute duties, Dworkin believes that he can also reject the weaker version's claim that social rules merely enable us to recognize duties. I shall argue that rejection of the strong claim does not entail rejecting the weaker claim. Furthermore, I try to show that Dworkin's argument against the weaker claim is fallacious, and that he is therefore not justifted in rejecting the weaker version of the social rule theory. But if the weaker version can support the thesis that the rule of recognition is a social rule or set of rules, as I believe it can, Dworkin may not be justified in his rejection of the first tenet of positivism.

One can put the matter in yet another way. Dworkin argues, successfully, that social rules, as expressed in uniform social practices, cannot set the limit of our duties; that is, social rules do not themselves constitute duties. He also argues that they cannot set the threshold, that is, that they cannot point beyond themselves to something more fundamental, such as duties. I shall try to show that some social rules can and do point beyond themselves to something more fundamental, namely to duties, and I shall try to show how Dworkin's argument against this claim fails. In this way I hope to establish the weaker version of the social rule theory, and with it the positivist's claim that the rule of recognition is a social rule or complex set of social rules.

Dworkin's example of the vegetarian shows why he rejects the social rule theory as an account of the origin of rights and duties." The vegetarian asserts that we have no right to $\mathrm{kill}$ animals for food because of the existence of a general moral duty to respect ilfe. In asserting that we have a duty not to kill animals, the vegetarian is not appealing to some social rule that is constituted by a uniform social practice. for no such uniform practice in fact exists. Nor is the vegetarian claiming that we ought to have this duty, even though we do not actually have it, that is, even though it has not been constituted by an actual social rule. What the vegetarian is claiming is that we do in fact have a moral duty not to kill animals, and that this duty ought to be the basis for a social rule that animals should not be killed. The upshot of this analysis 18 that the social rule theory has put the cart before the horse in claiming that social practices constitute rules that impose duties. According to Dworkin, duties, as well as the rules that express them, are not constituted by social practices. The example of the vegetarian is helpful because it reveals the reason that Dworkin rejects the claim that social rules constitute duties: duties are more fundamental than social practices. Thus, it is a mistake to think 
that social rules alone can somehow generate or impose duties.

So, for example, if a judge should ask the question. "Why is it my duty to take into consideration constitutional law in deciding a case in which freedom of speech is at isgue?," a satisfactory answer, for Dworkin, would never be, "Because there is a uniform social practice among judges of considering constitutional law in deciding cases dealing with first amendment rights." But this is precisely the kind of answer that the social rule theory advocates. For Dworkin, however, this reply simply does not suffice; the fact that judges do take some kinds of considerations into account in deciding particular cases does not provide the reason why Judges have a duty to do so.

I find Dworkin's arguments against the social rule theory convincing; he seems to me to be justified in rejecting $1 t$ as an inaccurate account of the origin and existence of duties." Dworkin seems correct in rejectIng the strong version's claim that the existence of social rules alone constitutes duties. But the rejection of this strong claim does not entall rejecting the weaker claim that social rules can point beyond themselves to something more fundamental, thereby enabling us to recognize duties. In fact, the argument that Dworkin uses against the weaker claim is fallacious.

He says:

I should like to point out, however, the weakness that remains in even this revised form of the social rule theory. It does not conform with our moral practice to say even that a social rule stipulates the minimum level of rights and duties. It is generally recognized, even as a feature of conventional morality. that practices that are pointless. or inconsistent in principle with other requirements of morality, do not impose duties... .

I take the following to be a fair reconstruction of Dworkin's argument:

(1) If social rules set the threshold of duties, then they must point beyond themselves to something more fundamental.

(2) But some social rules are trivial, and do not point beyond themselves to anything more fundamental.

(3) Therefore, no social rule can set the threshold of duties.

But this argument is fallacious. Dworkin reaches the wrong conclusion. The correct conclusion is: 
(3') Some social rules cannot set the threshold of duties. IThis conclusion is perfectly consistent with the thesis that the rule of recognition is a social rule or set of social rules that enables Judges to recognize their more fundamental duty to decide particular cases in particular ways, that 18. to take certain kinds of considerations into account when deciding certain kinds of cases. Eor although it is true that some social rules are undoubtedly trivial and do not point beyond themselves to anything more fundamental, it is just as true that some are meaningful and enable us to recognize our duties.]

Some examples may illustrate this point. Traffic rules provide a good example of social rules that do not constitute duties, but enable us to recognize what our duties are. Consider the rule that all drivers must stop for red lights. If we were traveling in a forelgn country, we could know that such a social rule exists by observing that a uniform social practice of stopping for red lights exists. By observing that a social rule exists, we might then infer that if one lives in the area in which the observations have been made and can.drive, one has some kind of duty or obligation to conform to the established social practice, and obey the rule of stopping for red lights. But we have no way of knowing, from the mere observation that the social rule exists, the origin or nature of the duty that the rule enables us to recognize. We might think that the social rule of stopping for red $11 \mathrm{ghts}$ itself constitutes or creates a duty to obey the rule, that is, that the mere fact that everyone seems to stop for red lighte creates an obligation for us to do 80 . But this would be incorrect. In fact, the duty to stop for red lights is not created by a social practice, but rather by a legislated traffic law. The duty is primarily legal in character, though it may have social and moral ramifications. In other words, the duty that we must stop for red lights is more fundamental than the social practice that everyone does in fact stop for red lights. To say that a social practice constitutes a duty is, in a sense, to confuse the is/ought distinction. The fact that everyone does something does not entail the normative claim that they must or ought to do it. However, from the fact that a social rule or practice exists, we may infer or recognize that some kind of corresponding duty to obey the rule or conform to the practice exists, although this need not always be the case.

Someone might object that the example of traffic rules begs the question of whether social rules enable us to recognize our duties. For most of us know that, in general, traffic rules, and, a fortiori, the social practice of obeying them, exist only by virtue of hav- 
Ing been enacted by a legislature. That is, it is true that the social rule of stopping for red lights does enable us to recognize a more fundamental duty, but only because we know the duty to have been imposed by a legislative enactment. Is it the case that some social practices can allow us to recognize duties of which we had no prior knowledge? I belleve so. Consider the social practice of keeping promises. It seems to be a relatively important practice; it fosters mutual trust and respect among individuals and thus helps to stabl1ize social interactions. As such, it is beneficial both to society and to the individual. Does the social rule that promises should be kept, which 1s brought about by the widespread practice of keeping promises, point to a more fundamental moral duty? Erom the observable fact that such a social rule exists and is beneficial to society. can we justifiably infer that we have a duty to keep our promises? I belleve that we can, espectaily if we take our membership in society seriously.

We oaid that the practice of keeping promises benefits society. If we take our membership in soclety gerlously, then we will be likely to believe that we have certain duties vis-a-vis our community by virtue of our citizenship. such as the duty to obey iaws and to conduct our lives in an orderly way. We may believe that we have the negative duty to refrain from engaging in activities that might harm the community. or even that we have the positive duty to engage in activities that would benefit 1 . Although these are not specifically legal duties, they are general moral duties that we might recognize ourselves as having by virtue of being members of a particular society. Given that we recognize that we have these general moral dutles, we may be able to infer from the existence of a meaningful social rule that benefits the community. such as the rule that promises should be kept, that we have a moral duty to obey that rule, and keep our promises. The particular duty of keeping promises is not constituted by the social rule itself, but rather is a conseguence of the fact that we accept certain general duties to contribute to society, or at least to refrain from hindering it. Moreover, we probably would not recognize that we have a moral duty to keep promises if the social rule did not exist, yet we still would have that duty, if we accepted the general duty to act in ways that benefit society.

clearly, then, there are some duties, such as the duty to obey traffic laws and the duty to keep one's promises, that exist whether or not there is a social rule that enables us to recognize them. So, contrary to the social rule theory. It is not the case that ". . no rights or duties of any sort can exist except by virtue of a uniform social practice of recognizing these rights and duties." "But, neither is it 
the case, as Dworkin thinks, that no uniform social practice can enable us to recognize or infer to the existence of rights and duties more fundamental than the practice itself. But 18 it the case that the rule of recognition is a meaningful social practice, a rule or set of rules that enables judges to recognize their more fundamental duty to decide particular cases in particular ways?

If it is the case that the weaker version of the social rule theory is correct, and the rule of recognition is a meaningful social rule or set of rules, this, according to Dworkin, no longer supports the positivist's thesis that such a rule of recognition accounts for all judicial duty. As he puts it. "If judges may have a duty to decide a case in a particular way, in spite of the fact that no social rule imposes that duty. then Hart's claim that social practice accounts for all judicial duty is lost." If a social rule of recognition is construed in the weaker sense of merely enabling judges to recognize their duty, rather than in the strong sense of actually constituting their duty. it is true that such a social rule no longer accounts for all judicial duty. Nonetheless, a case can be made for the claim that it accounts for a significant part of that duty.

But if this is the case, then some version of the rule of recognition might be developed that is compatible with both the positivist's and Dworkin's conceptions of law." For Dworkin's rejection of the thesis that the rule of recognition is a social rule or set of rules is motivated by the consideration that ". . positivism, with 1 ts doctrine of a fundamental and commonly-recognized test for law, mistakes part of the domain of that concept for the whole."I But a version of the rule of recognition that delimits only a part of judicial duty, yet points beyond itself to other aspects of that duty, avoids the charge of mistaking a part of the field of law for the whole. A parallel can be drawn between judicial duty and the duty to keep one's promises. The social rule that promises should be kept not only points beyond itself to the particular duty of promise-keeping, it also suggests a number of more general moral duties and considerations, auch as the duty to act in ways that benefit society, or the duty not to harm others, or the duty to respect persons. That 18 , the particular duty of promise-keeping does not exist in a moral vacuum; it is one of a number of interrelated considerations that comprise the fleld of morality. We may keep our promises because we believe that we have a duty to do so, but our belief that we have that particular duty may rest on further beliefs about other moral duties that we have, such as those mentioned.

A similar point can be made with respect to judicial duty. Consider, for example, the social rule 
among fudges of accepting the constitution and its amendments as the rule of law in deciding cases dealing with first amendment rights. The judicial practice of accepting the constitution and 1 ts amendments as the rule of law in such cases may point beyond 1 tself to a more fundamental moral duty to take these documents into account. But the particular duty to consider these documents as the rule of law in such cases does not exlst in a vacuum; it is just one of a number of interrelated duties that comprise the field of political morality. Other fudiclal duties that are suggested by the duty to accept the constitution and 1 ts amendments as law are. for example, the duty to consider the principles of political morality that form the underpinning of these documents, or the duty to consider the intent of the authors in framing the documents, that is, to consider the spirit as well as the letter of the law in deciding cases that deal with first amendment rights.

Construed in this way, a social rule of recognition would not mistake part of the domain of law for the whole. For it would enable judges to recognize as law not only the rules that are explicitly stated in legal documents such as the constitution and statutes, but would also enable them to recognize the principles of political morality that underlie as well as pervade these documents. Such a version of the rule of recognition would ourely be acceptable to Dworkin, for it avoids his main objection to the positivist doctrine of a social rule of recognition--that a test of pedigree alone cannot be broad enough to include, as part of the law, principles that embody commonly accepted moral precepts."2 It might also be acceptable to some positivists, namely, to those concerned to defend the thesis that the rule of recognition 18 a soclal rule or set of rules. Of course, it would not be acceptable to positivists who wish to maintain the strict separation of law and morals.

What is the upshot of all of this for Dworkin? If, as I have argued, his arguments against the social rule theory fail to refute the thesis that the rule of recognition may be a social rule or get of rules, and if a plausibie version of this thesis avoids his main charge that a social rule mistakes part of the domain of law for the whole. Dworkin may be forced to reassess some attempts at developing a version of a social rule of recognition that satisfies both his conception of law and that of positivists.is Eurthermore, he may be forced to teassess his own alternative to a social rule of recognition--a version of the thesis that $n$. . . In every legal system some particular normative rule or principle. or complex set of these, is the proper standard for judges to use in identifying more particular rules or principles of law." "Dworkin sketches his view of the process of judiclal decision-making in "Hard Cases," "sut surely he cannot intend this ac- 
count either as an accurate description of the way in which judges actually decide cases, or as a practical suggestion for Improving the current procedure. For Dworkin's idealized account of that process presupposes super-human knowledge and legal skill, absolute impartiality, and infinite patience and endurance. Its complexity is stunning. Its lack of plausibility alone should lead Dworkin to reconsider the merits of a social rule of recognition. The failure of his arguments against the weaker version of the social rule theory surely should do so.

\section{NOTES}

'Ronald Dworkin, Taking Rights Seriously (Cambridge, Mass.: Harvard University Press, 1977, 1978), pp. 14-45.

${ }^{2}$ Dworkin, p. 48 .

'The social rule theory is developed by H. L. A. Hart in The Concept of Law (London: Oxford University Press, 1961), pp. 79-88.

'Dworkin, p. 54.

'Dworkin, pp. 52-53.

'Dworkin's detailed arguments are set out in Dworkin, pp. 48-64. A full account of these would take us too far afleld of the purpose of this paper.

'Dworkin, p. 57.

'Dworkin, p. 48.

'Dworkin, p. 57.

"For a list of some of Dworkin's respondents on this issue, see Dworkin, p. 46, footnote 2 .

'Dworkin, p. 47.

${ }^{22}$ Dworkin, Pp. 40-43.

"In particular, he may need to reexamine the proposal made by Raz that a social rule of recognition can be found in the concept of "judicial custom" (see Joseph Raz, "Legal Principles and the Limits of Law," 81 Yale Law Journal 823 (1972) pp. 851-854), and that made by Sartorius that it can be found in the concept 
of "Institutional support" (see Sartorius, "Social Pollcy and Judiclal Legisiation," 8 American Philosophlcal Quarterly 151 (1971) pp. $\overline{155-156)}$. Aithough Dworkin gives a detalled response to Sartorius' proposal, he gives Raz's interesting suggestion rather summary treatment, in fact, he dispenses with it in only two paragraphs (see Dworkin, pp. 64-65).

"Dworkin, p. 60.

"Dwork1n, pp. 105-130. 